\title{
Early Detection of Cercospora Species in Soybean Plants: Immunologic and Molecular Methods
}

\author{
María Gabriela Latorre Rapelaํ, María Cristina Lurá1, Iván Marcipar² \\ ${ }^{1}$ Cátedra de Microbiología General, Facultad de Bioquímica y Ciencias Biológicas, Universidad Nacional del \\ Litoral, Santa Fe, Argentina \\ ${ }^{2}$ Cátedra de Tecnología Inmunológica, Facultad de Bioquímica y Ciencias Biológicas, Universidad Nacional del \\ Litoral, Santa Fe, Argentina \\ Email: latorrerapela@gmail.com
}

Received 13 August 2015; accepted 20 November 2015; published 25 November 2015

Copyright (C) 2015 by authors and Scientific Research Publishing Inc.

This work is licensed under the Creative Commons Attribution International License (CC BY).

http://creativecommons.org/licenses/by/4.0/

(c) (i) Open Access

\section{Abstract}

Late-cycle diseases (LCD) cause a significant deterioration in quality and reduce yields in soybean crops. In Argentina, in particular, leaf blight and purple seed stain, caused by the agent Cercospora kikuchii, and frog eye spot, caused by $C$. sojina, are the prevailing sources of diseases. The early, rapid and accurate detection of these phytopathogens becomes essential, and would contribute to preserving both the environment and the health of humans and animals by preventing the wasteful or improper use of chemicals such as pesticides. In order to detect Cercospora species in soybean plants at an early stage, immunochemical and molecular techniques were developed in this work. Strains from the NITE Biological Resource Center collection (Japan): Cercospora kikuchii NBRC 6711 and Cercospora sojina NBRC 6715 and regional isolates of $C$. kikuchii were used. To develop Dot-Blot and PCR techniques, experiments with plants undergoing different treatments were carried out: those experimentally inoculated with these fungi, those treated with sterile water and healthy plants as well. Both techniques allowed the detection, at early stages, of Cercospora species involved in two of the most frequent LCD in the country, when the cercosporin concentration produced by the fungus was higher than $3.93 \pm 0.39 \mathrm{nmol}^{\circ} \cdot \mathrm{cyl}^{-1} \pm \mathrm{SD}$. The sensitivity between both techniques was very different. While Dot-Blot allowed the detection of the disease 4 days after inoculation, PCR detected it after 4 hours, even without visible symptoms of the disease.

\section{Keywords}

Cercospora kikuchii, Cercospora sojina, Dot-Blot, PCR, Late-Cycle Diseases 


\section{Introduction}

Late-cycle diseases (LCD) are very frequent in soybean crops, quality deterioration and yield decrease being the ordinary consequences. One of the main problems associated with these diseases is that visible symptoms appear only at intermediate or advanced stages, close to the harvest time [1].

Among the causative agents of LCD, Cercospora genus species are a major problem. In Argentina, in particular, leaf blight and purple seed stain, whose agent is Cercospora kikuchii, and frog eye spot, caused by C. soji$n a$, are common diseases that reduce the plant nutritional value and lead to severe crop damage [1] [2]. One of the main pathogenicity factors, shared by many species of this genus, has been demonstrated to be a red toxin called cercosporin. Its production is regulated by CFP (Cercosporin Facilitator Protein), which is specific of the genus and coded by the gene $c f p$ (cercosporin facilitator protein) [3]. CFP also exports cercosporin out of the fungus [4], which suggests that the gene plays a fundamental role in toxin production regulation. Therefore, the detection of the $c f p$ gene in an infected plant would indicate the presence of a fungus capable of producing cercosporin and consequently, causing the disease.

Plants highly affected lose a large amount of foliage, resulting in an anticipated maturity with an inadequate filling of pods and a reduced germination of seeds. These pathologies can be controlled by many strategies such as the application of fertilizers, fungicides and herbicides, combined with the use of cultivars of greater genetic potential, the massive diffusion of transgenic materials in soybean and handling practices like direct sowing [5].

In general, the diagnosis of fungal phytopathogens is based on the observation of signs and symptoms of the disease which, in the case under study, are visible only when the disease is at an advanced stage. Hence, the early, rapid and accurate detection of these phytopathogens becomes essential, and would contribute to preserving both the environment and the health of humans and animals by preventing the wasteful or improper use of chemicals such as pesticides [6].

As a result of advances in biotechnology, new procedures, such as immunochemical and molecular techniques, are today available to complement or replace the traditional laboratory procedures, so as to accelerate the achievement of results and enable an earlier diagnosis of diseases [7]. Diseases caused by microorganisms can be diagnosed by identifying a unique characteristic of the organism, such as a protein or its genetic material.

Among the various immunochemical techniques, Dot-ELISA or Dot-Blot appear as a more versatile technique applicable to the diagnosis of a large number of samples [8] [9]. It is a rapid ELISA that uses as solid support nitrocellulose paper, characterized by an excellent capacity to adsorb proteins [10]. The (synthetic or recombinant) antigen is usually passively adsorbed (blotting) to the support dropwise ("dot”). This immunoassay is economic and easy to implement since it generates an insoluble, colored precipitate which allows the reaction to be followed by a visual reading [11].

PCR, on the other hand, is a technique with great advantages in fungi identification. It is a rapid method, since the process of extraction and amplification of DNA and electrophoresis can be performed in $24 \mathrm{~h}$, which substantially reduces the diagnosis time as compared to the conventional methods-direct examination of colonies and culture [12]. Its high sensitivity allows detecting low concentrations of the DNA to be amplified in almost any type of sample and with high specificity, which is determined by the sequence of oligonucleotides used and the DNA annealing conditions [13] [14]. Though having all these advantages, a specific laboratory infrastructure, expensive equipment and trained personnel are required, all of which are not always available.

In order to provide tools for the detection of Cercospora species in soybean plants at an early stage in laboratories with high or low level of complexity, both an immunochemical (Dot-Blot) technique requiring low level of complexity and a molecular (PCR) technique demanding higher complexity laboratories were developed in this work.

\section{Materials and Methods}

\subsection{Fungi Used}

The following strains, belonging to NITE Biological Resource Center (Japan) collection, were used in the experience: Cercospora kikuchii NBRC 6711 (CK6711) and Cercospora sojina NBRC 6715 (CS6715), as well as regional isolates of $C$. kikuchii, which produced cercosporin in high (CK32, $148.51 \pm 3.98 \mathrm{nmol}_{\mathrm{c}} \mathrm{cyl}^{-1} \pm \mathrm{SD}$ ) and

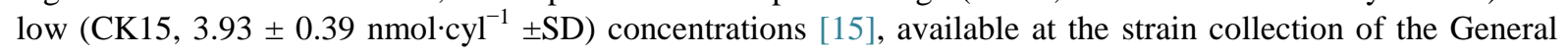
Microbiology chair at the Facultad de Bioquímica y Ciencias Biológicas of Universidad Nacional del Litoral 
(FBCB-UNL). A Penicillium sp. isolate was also included for genus specificity study [16].

\subsection{Plants Used}

Plants at phenological stage V3, experimentally inoculated with CK6711, CS6715, CK15 and CK32, as described in Latorre Rapela et al. [17], were used in the experiment. Healthy plants (negative control) and plants treated with sterile water were also used.

In order to determine how early the fungus could be detected, different sampling times ( 4 and $24 \mathrm{~h}$, and 2, 4 and 6 days) were set, since in previous tests, lesions had been visible to the naked eye in plants infected with Cercospora 5 days after inoculation.

\subsection{Dot-Blot Technique}

\subsubsection{Obtaining Recombinant CFP Protein and Anti-CFP Antibodies}

The amino acid sequence of CFP has 607 amino acids [3], the antigenic region being located at the C-terminal part and entirely coded in the last exon of the gene (2628 bp $\cdots>3150$ bp) (Genbank accession number: AF091042).

Specific primers -"Forward" (FP: 5-gtcctgcccgatgctca-3) and "Reverse" (RP: 5- tcacactgcttgcccac-3)-were designed using the DNA Start Sequence Analysis Software program. These ones were selected between the set of primers suggested by the program taking into account the highest score to amplify nearly all the exon coding region. Primers were synthetized by Genbiotech SRL (Argentina). The selected fragment was ligated firstly to the plasmid vector pGEM-TEasy (Promega ${ }^{\circledR}$, EE.UU) and then to the expression vector pET-32a (Novagene, EE.UU). Plasmids ligated to PCR amplicon were transformed into Escherichia coli BL21 (DE3).

The recombinant protein obtained was purified in an IDA-Sepharose (Novagen, U.S.A) column, over which $\mathrm{Ni}^{2+}$ was immobilized.

The specific anti-CFP antibodies were obtained from a rabbit immunized with such protein. Immunization was carried out at the Centro de Experimentaciones Biológicas y Bioterio of Facultad de Ciencias VeterinariasUniversidad Nacional del Litoral (FCV-UNL).

\subsubsection{CFP Protein Extraction}

The extraction of the CFP protein was carried out according to the protocol proposed by Rollins et al. [18], weighing $100 \mathrm{mg}$ of powdered fungal mycelium corresponding to CK6711 and CS6715 (positive controls) and Penicillium sp. (negative control) and $100 \mathrm{mg}$ of plant tissue infected with CK32. One $\mathrm{ml}$ of extraction buffer was added to each tube and incubated overnight at $4^{\circ} \mathrm{C}$ in the dark. After centrifugation at maximum speed (13,000 rpm) for $10 \mathrm{~min}$, the supernatant were transferred to respective Eppendorf tubes and stored at $-20^{\circ} \mathrm{C}$ until processing.

Total protein determination was performed following Bradford technique [19]. The same methodology was applied to plants treated with water and to the uninoculated. Extractions were carried out with samples taken at 4 and $24 \mathrm{~h}$ and 2, 4 and 6 days after inoculations.

\subsubsection{Adsorption of Nonspecific Antibodies from Rabbit Serum}

For adsorption of nonspecific antibodies, nitrocellulose membrane strips were cut, placed into an Eppendorf tube and embedded with protein extract of the fungus CK15. They were then removed and let dry at room temperature. When dry enough, the membranes were placed into another Eppendorf tube with $1 \mathrm{ml}$ of rabbit serum, stirring for 30 min at room temperature [20].

The procedure was repeated at least 5 times. Finally the adsorbed serum was collected in another Eppendorf tube, fractionated and kept at $-20^{\circ} \mathrm{C}$ until use.

The presence of antibodies specific for the native protein of CK6711 in the adsorbed serum was determined by Western blot.

\subsubsection{Development of Dot-Blot Technique and Determination of Cut-Off Line}

The following procedure was applied to every extract obtained: $1 \mu \mathrm{l}$ of the pure soluble extract, followed by decreasing amounts $(1 / 2,1 / 8,1 / 32$ and 1/64) of this same extract was placed on a nitrocellulose membrane, so as to fix the antigen (CFP protein) on the membrane in decreasing amounts. Each extract was allowed to dry at 
room temperature and blocked with PBS (Phosphate Buffered Saline-Tris)-skim milk 5\% for 60 min. Afterwards, three 5 min washing cycles with PBS-T were performed. It was then incubated for $1 \mathrm{~h}$ in a vial with $1 \mathrm{ml}$ of rabbit serum adsorbed (1:500) on 1\% PBS-milk, subjected to three new washes and incubated again for $1 \mathrm{~h}$ with $1 \mathrm{ml}$ of anti-IgG total rabbit serum conjugated with peroxidase (diluted 1/500 with 1\% PBS). After a new three times-washing step, the membranes were treated with a solution of PBS, hydrogen peroxide $0.4 \%$ and $3 \%$, 3'-diaminobenzidine (Sigma Chemical Co.) for $20 \mathrm{~min}$. The reaction was stopped by washing with water.

All incubation steps were carried out at moderate stirring. All experiments were carried out in duplicate.

This method was designed to facilitate visual reading while decreasing the subjectivity of observations. The applied principle is the semi quantification of the amount of CFP protein present in the plant extracts, while dots were loaded using decreasing amounts of the extract. As a result, more dots are recognized, more amount of protein is present in the sample. Notwithstanding, a weakness of Dot-Blot method for diagnostic purpose is that different users may interpret a weak signal as positive or negative. Then if the result is expressed based only in the last blot with the minimal signal, the variability of the informed result for a defined sampled might be high between users. To obtain a more accurate visual lecture, the signals for the five dots corresponding to a single sample were registered as high or low and were integrated in a score. Every signal obtained on the membrane was considered to have a numerical basis of 4, 2 or 1, depending on the strength of the signal (very strong, low or light, or not visible, respectively). Then, these signals were integrated in a score by multiplying them together. Indeed, different criteria were tested to determine the best way to integrate the signals and the product showed the best discrimination between positives and negatives samples (data not shown).

Once the score was obtained, a cut-off line was defined through the ROC (Receiver Operating Characteristic) curve with the MedCalc program, in order to obtain the best discrimination between reactive and nonreactive samples. For this purpose, plants with symptoms of Cercospora disease and healthy plants were used. CK6711 was also included as a positive control. The score was considered less than or equal to 2 for healthy plants and greater than or equal to 4 for infected plants, so that the score value equal to or less than 2 was considered as a marker of lack of CFP in the leaf tissue.

\subsection{PCR Technique}

\section{Extraction of Total DNA from the Samples and $c f p$ Gen Identification}

The extraction of total DNA from fungus and plant tissue was carried out according to Lee and Taylor [21] protocol. DNA quality was evaluated by electrophoresis in agarose gel [22].

In a first test, primers FP and RP, previously designed to amplify the coding sequence fragment were used, evaluating different reaction conditions with the DNA of the CK6711 fungus. This technique was carried out with DNA of plants inoculated with the regional isolates CK32 and CK15, using DNA of CK6711 and CS6715 as positive controls.

Then, new primers were designed in order to increase specificity with plant tissues. For this purpose, the alignment and computer analysis of the sequence corresponding to the last exon of the gene, deposited in the GenBank (Accession number AF091042), was made. The program DNA start Sequence Analysis Software was applied, selecting those primers with the highest score (CFP-1: 5-tgaggtcgcagagcaagcat-3 and CFP -2: 5cgcgtcgtcccattagttttct-3), which were then sent for synthesis to Genbiotech SRL.

For each DNA from fungus and plant tissue obtained, amplification reactions were conducted in a total volume of $50 \mu \mathrm{l}$, with $20 \mathrm{ng}$ of DNA and $5 \mu \mathrm{l}$ of reaction buffer $1 \times$ (InbioHighway, Argentina), $1.5 \mathrm{mM} \mathrm{MgCl}_{2}$, $0.2 \mathrm{mM}$ of each dNTPs (Inbio Highway, Argentina), $0.2 \mu \mathrm{M}$ of each oligonucleotide and $2.5 \mathrm{U}$ of Taq DNA polymerase (Inbio Highway, Argentina). Mineral oil (15 $\mu \mathrm{l})$ was added at the end of the reaction.

Amplification was carried out as follows: one 3 min denaturalization cycle at $95^{\circ} \mathrm{C}$; 35 cycles comprising 1 min at $58^{\circ} \mathrm{C}, 1 \mathrm{~min}$ at $72^{\circ} \mathrm{C}$ and $1 \mathrm{~min}$ at $95^{\circ} \mathrm{C}$, with a final extension cycle of $5 \mathrm{~min}$ at $72^{\circ} \mathrm{C}$.

Amplification products were separated by electrophoresis on horizontal submerged agarose gels $(1.5 \% \mathrm{w} / \mathrm{v})$ with TBE $0.5 \times$ (Tris-borate $0.089 \mathrm{M}$, EDTA $0.002 \mathrm{M}$ ) [22]. Runtime took $180 \mathrm{~min}$, with a constant voltage of $100 \mathrm{~V}$. The gel staining was performed with ethidium bromide and 100-bp DNA Ladder (Inbio Highway, Argentina) was used as MW marker.

All experiments were carried out in duplicate.

The band profile obtained was photographed with Gel Doc XR System (BIORAD-Life Science Cat. \# 170 8170) using Quantity One Software. 
This test was applied to DNA of the plants inoculated with the regional isolates CK32 and CK15, using DNA of CK6711 and CS6715 as positive controls.

\section{Results}

The homology between $c f p$ sequence and Cercospora genus species was corroborated (using BLAST program) when seeking for identity in GenBank database. No homology was found with gene sequences of other fungal species indexed so far.

Figure 1 shows the schematic representation of $c f p$ gene regions which are found in the last exon coding CFP protein, its $C$ terminal region being expressed for the immunochemical test (451 bp) and sequence of 264 bp being used for PCR.

\subsection{Dot-Blot Technique}

The results of Dot-Blot technique are shown in Figure 2, where signs of different intensity can be seen, whether they correspond to healthy (lines 9 - 15) or infected plants (lines 1 - 8).

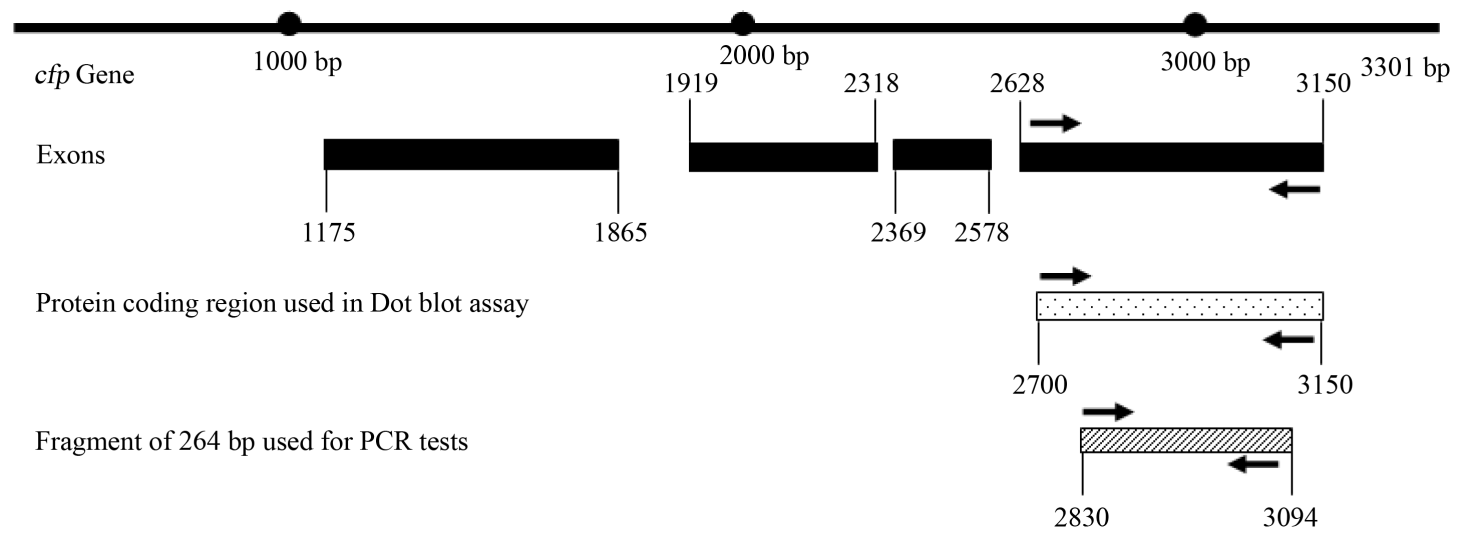

Figure 1. Schematic representation of the $c f p$ gene regions used.

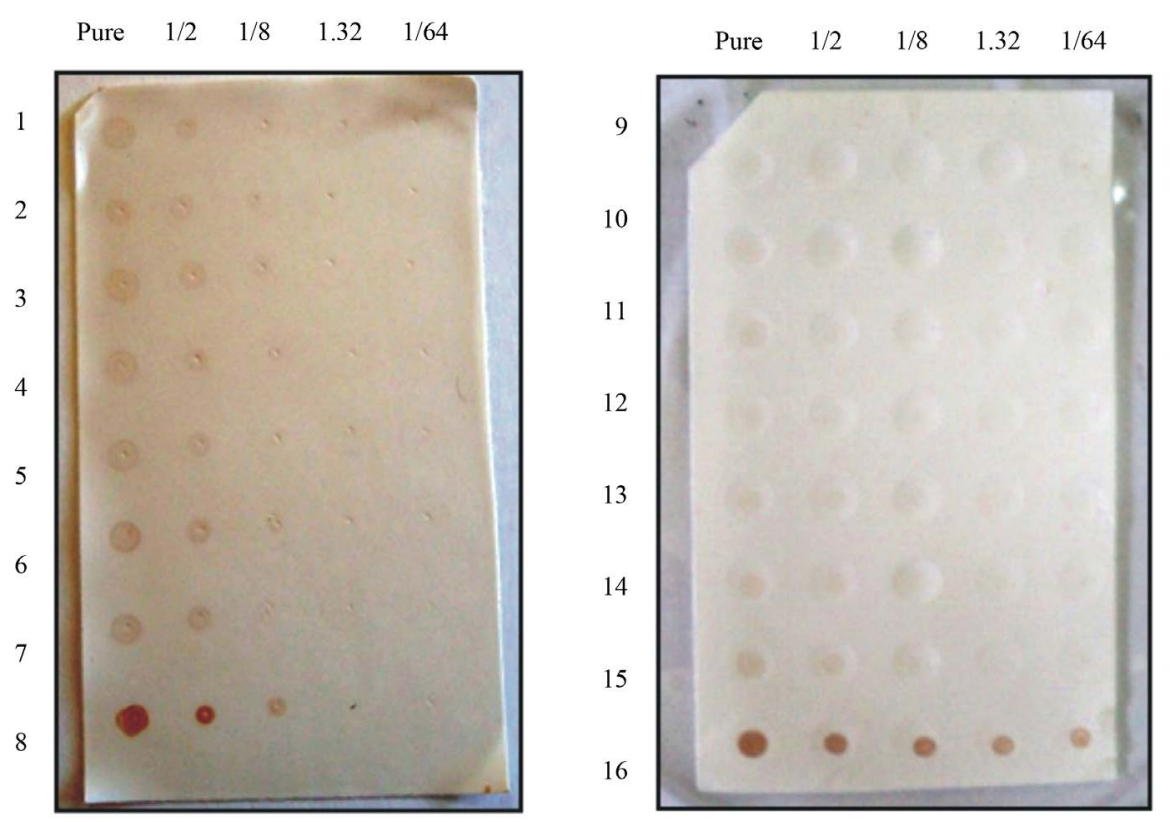

Figure 2. Dot-Blot of soluble extracts from plants and positive control. Lines 1 - 8: plants with symptoms of the disease; lines 9 - 15: healthy plants; line 16: Cercospora kikuchii NBRC 6711 (positive control). 
The score of each sample is shown in Table 1.

According to the criterion adopted, the extracts of the reference strains CK6711 and CS6715 showed score values higher than 4, whereas Penicillium sp. extract (negative control) had a value less than 2 .

Four days after inoculation, every plant extract inoculated with regional isolate CK32 showed a score 32, which indicated the presence of CFP protein in the leaf tissue. Plants collected 4 and $24 \mathrm{~h}$ and 2 days post-inoculation showed values less than 2 , as well as plants treated with sterile water and uninoculated ones.

Score values between 128 and 512 appeared for the positive control, whereas it was 1 for the negative control. As an example, Dot-Blot images applied to extracts of plants infected with CK6711 at different times post-inoculation are shown (Figure 3). Similar results were obtained with extracts of plants infected with CS6715.

\subsection{PCR Technique}

When separating the amplification products obtained with oligonucleotides FP and RP, the fungus corresponding to the reference strain could be seen to give a clear band at $451 \mathrm{bp}$, approximately; however, both infected and healthy plants showed nonspecific bands.

Use of oligonucleotides CFP-1 and CFP-2 allowed the amplification of an inner portion of the cfp fragment (about 264 bp). This fragment became visible $4 \mathrm{~h}$ after plant inoculation with the reference strains CK6711 and CS6715 and the regional isolate CK32. This signal intensified with time.

No amplification was detected for any of the sampling times in uninoculated plants and plants treated with sterile water. The same response was observed in samples obtained from plants inoculated with CK15, a producer of low concentration of cercosporin.

As an example, Figure 4 shows one of the results obtained with PCR technique.

Table 1. Score value determination for extracts of plants and positive control.

\begin{tabular}{|c|c|c|c|c|c|}
\hline Sample $^{\mathrm{a}}$ & $\begin{array}{l}\text { Dot-Blot intensity and } \\
\text { score calculation }\end{array}$ & Score & Sample $^{a}$ & $\begin{array}{l}\text { Dot-Blot intensity and } \\
\text { score calculation }\end{array}$ & Score \\
\hline 1 & $2 \times 2 \times 2 \times 1 \times 1$ & 8 & 9 & $1 \times 1 \times 1 \times 1 \times 1$ & 1 \\
\hline 2 & $2 \times 2 \times 2 \times 1 \times 1$ & 8 & 10 & $2 \times 1 \times 1 \times 1 \times 1$ & 2 \\
\hline 3 & $2 \times 2 \times 2 \times 1 \times 1$ & 8 & 11 & $2 \times 1 \times 1 \times 1 \times 1$ & 2 \\
\hline 4 & $2 \times 2 \times 2 \times 1 \times 1$ & 8 & 12 & $1 \times 1 \times 1 \times 1 \times 1$ & 1 \\
\hline 5 & $2 \times 2 \times 2 \times 1 \times 1$ & 8 & 13 & $1 \times 1 \times 1 \times 1 \times 1$ & 1 \\
\hline 6 & $2 \times 2 \times 2 \times 1 \times 1$ & 8 & 14 & $2 \times 1 \times 1 \times 1 \times 1$ & 2 \\
\hline 7 & $2 \times 2 \times 2 \times 1 \times 1$ & 8 & 15 & $2 \times 1 \times 1 \times 1 \times 1$ & 2 \\
\hline 8 & $4 \times 4 \times 2 \times 1 \times 1$ & 32 & 16 & $4 \times 4 \times 4 \times 4 \times 4$ & 1024 \\
\hline
\end{tabular}

${ }^{\mathrm{a}}$ Samples 1 - 8: plants with symptoms of the disease; samples 9 - 15: plants without symptoms; Sample 16: Cercospora kikuchii NBRC 6711.
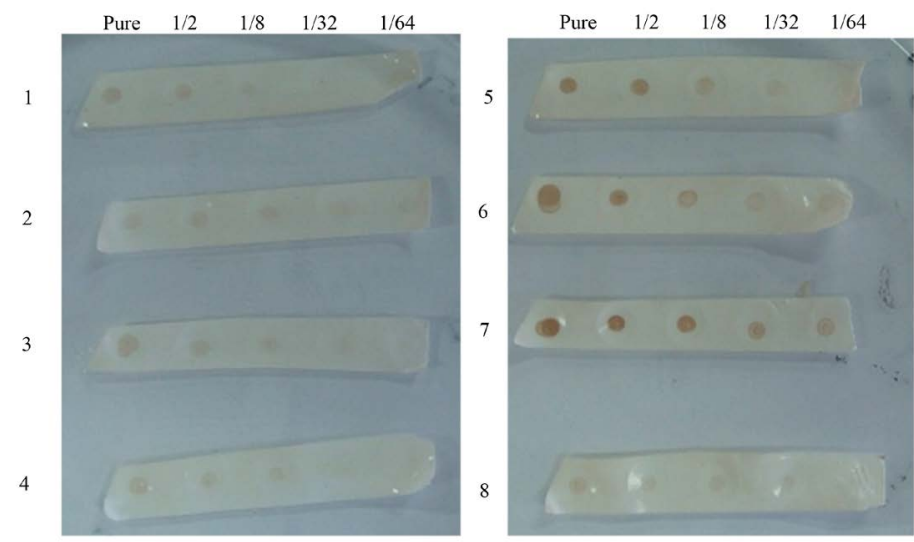

Figure 3. Images of Dot-Blot applied to extracts from plants infected with Cercospora kikuchii NBRC 6711 at different times post-inoculation. 1: plant inoculated with water; 2: uninoculated plant; 3, 4, 5 and 6: plants inoculated with Cercospora kikuchii NBRC 6711 and collected at 4 h, 24 h, 4 days and 6 days, respectively, 7: positive control (extract of C. kikuchii NBRC 6711); 8: negative control (extract of Penicillium sp.) 

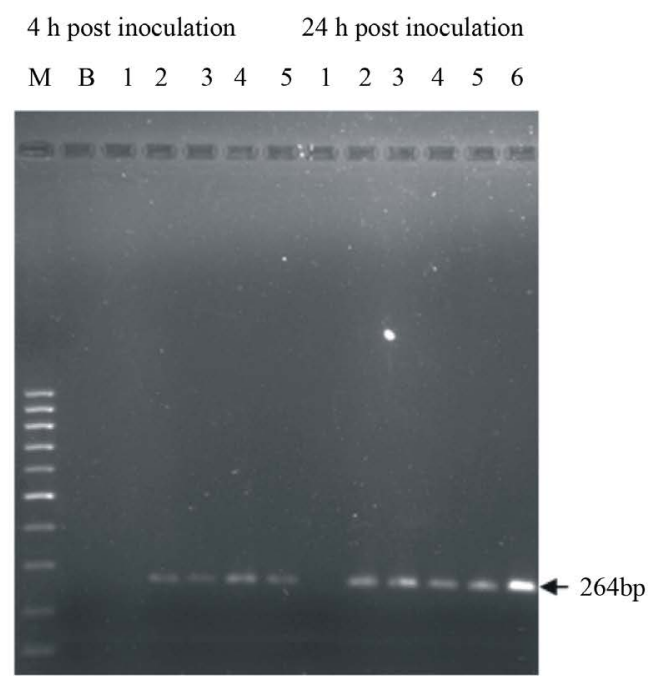
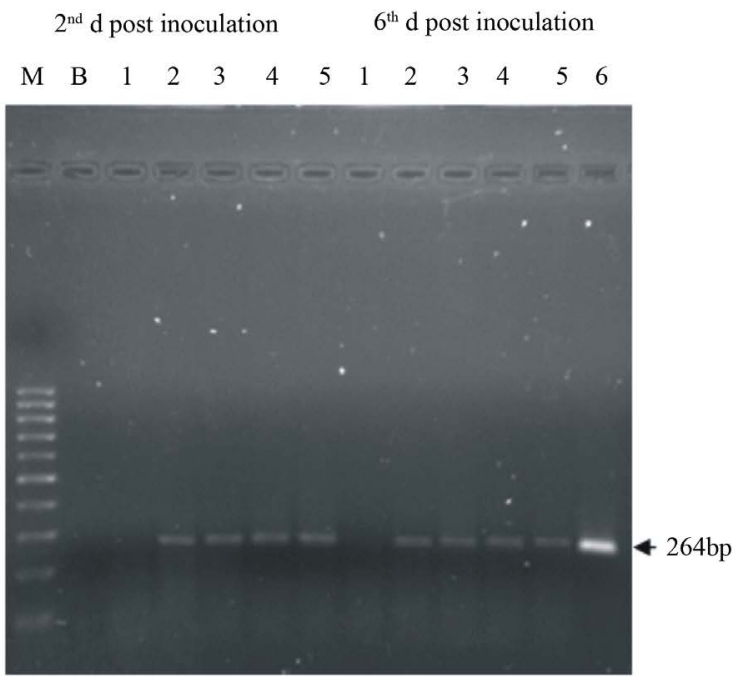

Figure 4. Amplification of $c f p$ fragment by PCR in soybeans, at different times post-inoculation. M: marker 100 bp DNA ladder (InbioHighway, Argentina); B: reagent blank; 1: plant treated with water; 2 and 3: plants inoculated with CK32; 4 and 5: plants inoculated with Cercospora sojina NBRC 6715; 6: positive control (Cercospora kikuchii NBRC 6711).

\section{Discussion}

Accurate and early identification of the involved pathogen, as well as disease diagnosis, are crucial requisites for a thorough understanding of plant diseases and appropriate decision-making on the effective measures to be taken for crop management.

Traditional methods for phytopathogen identification in the laboratory have turned out to be slow and vague, which has led to the search for specific, sensitive and fast detection techniques [23].

Evaluating the use of an immunochemical technique such as Dot-Blot or Dot-ELISA was the aim of this work. For good phytopathogen detection, a nitrocellulose membrane was used as an adsorption surface, since it allows the immobilization of more physicochemical characteristics of the antigens than ELISA plate [9].

Also, following Lartey et al. [20], it was decided to eliminate the nonspecific antibodies present in rabbit serum by adsorbing them with the extract of a fungus which does not produce CFP protein. With this purpose, the regional isolate CK15, which was a cercosporine low producer, was used in our experiment. When it grew on PDA (potato dextrose agar), no red pigment diffused to the medium, causing small chlorotic lesions on the leaf tissue of the soybean plant on which it was inoculated.

The adsorption allowed the elimination of nonspecific reactivities, and the incorporation of a score facilitated interpretation of results, thus resulting in an easy, fast and economic technique that could be used in the field as a screening method [24].

Dot-ELISA can be completed in less than $3 \mathrm{~h}$, allows the simultaneous processing of several samples and, as the interpretation of results is visual, the end point can be easily determined. It is one of the most versatile tests to detect either antigen or antibody and is adaptable to both laboratory and field conditions [8].

This technique has been used in Colombia to detect the mycotoxin beauvericin [25]. It has also been incorporated to the fast detection of different etiologic agents (parasites, bacteria and viruses) responsible for human diseases [8] [26]-[31].

Dot-Blot technique allowed the CFP protein detection 4 days after experimental inoculation, even when no disease symptoms were visible.

Besides the immunochemical technique, a molecular technique (PCR) was developed for the detection of Cercospora species attacking soybean.

In 1999, Xu et al. [32] developed a PCR technique which allowed detection of Sporisorium reiliana in maize, concluding that it was important to carry out epidemiological and etiological studies. This kind of methodology was also applied by other authors for detection of Phytophtora capsici in chile plants with wilt symptoms, using oligonucleotides directed against specific sequences of cutinase gene [13]. Pavon Moreno et al. [33], on the oth- 
er hand, were able to detect Alternaria spp. in fruit and vegetable products using oligonucleotids specific for the gene Alt a 1 coding for the main allergen of A. alternate.

Lartey et al. [34] presented a real-time PCR protocol for the rapid detection of $C$. beticola in sugar beet tissues, but, unlike this paper, they amplified a fragment corresponding to the Cercospora actin gene.

Results showed that oligonucleotides CFP-1 and CFP-2, designed to amplify an inner portion of cfp fragment, were highly specific of Cercospora species, so they could determine its presence from both DNA extractions of the fungus mycelium developed "in vitro" and plants inoculated with the fungus, even when no disease symptoms were observed. The gen was detected $4 \mathrm{~h}$ after experimental inoculation. It is important to point out that when PCR was conducted with plants inoculated with the regional isolate CK15, the 264 bp band corresponding to $c f p$ gene was not detected. It should be remembered that this fungus produced very low concentrations of cercosporin (3.93 $\pm 0.39 \mathrm{nmol} \cdot \mathrm{cyl}^{-1} \pm \mathrm{SD}$ ) and hence, small lesions, which could be due to a similar fact reported by Daub et al. [35]. They observed that $C$. kikuchii mutants exhibiting a cfp gene disruption produced a significant reduction both in cercosporin production and in soybean symptom development.

So far, these methodologies for Cercospora species detection have not been developed somewhere in the world. Chanda et al. [36] have carried on a quantitative PCR protocol for the detection of Cercospora kikuchii in soybean leaves using specific oligonucleotids for the CTB6 gene of C. kikuchii. These oligonucleotids are different from the ones described in this investigation and do not determine infections with different Cercospora species.

It is important to point out that in this paper, in both techniques, the two strains used yield coincident results, which is because such species produce cercosporin and its transport protein [37].

As a conclusion, the above described techniques allowed detection, at early stages, of the Cercospora species involved in two of the most frequent LCD in Argentina, when the cercosporin concentration produced by the fungus was higher than $3.93 \pm 0.39 \mathrm{nmol} \cdot \mathrm{cyl}^{-1} \pm \mathrm{SD}$.

However, sensitivity between both techniques was very different, since PCR always allowed detection at early stages of infection, without visible symptoms of the disease. The usefulness of both techniques should be confirmed by further validation with field samples. It has to be considered that this study was performed with the development of an experimental model to infect soy plants with Cercospora. This methodology has allowed reproducing infection symptoms in healthy plant tissues and determining how many hours and days after the inoculation the injuries were visible to the naked eye. This model allowed assessing the previously optimized techniques with high reliability. Unfortunately, a reliable assessment of the method in field crop would be difficult because there is no "gold standard" that allows to know, at early stages, the infection caused by this fungal genus and to determine the time of the crop infection in the field. Then an experimental infection in field crop would be necessary to validate this method.

\section{Acknowledgements}

This work was funded by grants from Universidad Nacional del Litoral, Argentina, CAID 2009. The authors would like to thank Eng. Roxana Maumary for her contribution with plant collection and the experimental pattern of soybean plants infected by Cercospora species.

\section{References}

[1] Couretot, L. and Ivancovich, A. (2010) Enfermedades de final de ciclo de la soja. In: Taller de Diagnóstico y manejo de Enfermedades de Soja, Secretaría de Agricultura, Ganadería, Pesca y Alimentos, Argentina, 5-10.

http://www.minagri.gob.ar/site/agricultura/roya soja/07=informes/01 Informes/ archivo/090000-Informes\%20campa \%C3\%B1as\%202009-2010/000000-Taller\%20de\%20Diagn\%C3\%B3stico\%20y\%20Manejo\%20de\%20Enfermedades \%20de\%20Soja\%20PNRS.pdf?PHPSESSID=d2f50273a1d4ccb6df37161bfdc1b76f.

[2] Carmona, M.A., Formento, N.A. and Scandiani, M.M. (2010) Manual mancha ojo de rana. Horizonte A, Buenos Aires.

[3] Callahan, T.M., Rose, M.S., Meade, M.J., Ehrenshaft, M. and Upchurch, R.G. (1999) CFP, the Putative Cercosporin Transporter of Cercospora kikuchii, Is Required for Wild Type Cercosporin Production, Resistance, and Virulence on Soybean. Molecular Plant-Microbe Interactions, 12, 901-910. http://dx.doi.org/10.1094/MPMI.1999.12.10.901

[4] Daub, M.E. and Chung, K.R. (2007) Cercosporin: A Photoactivated Toxin in Plant Disease. American Phytopathological Society netFeatures. http://dx.doi.org/10.1094/APSnetFeature/2007-0207

[5] Carmona, M. and Reis, E.M. (2009) Critério: sistema de pontuação para aplicação de fungicidas para as doenças de 
final de ciclo na cultura da soja. In: Reis, E.M., Ed., Critérios indicadores do momento para aplicação de fungicidas visando ao controle de doenças em soja e trigo, Aldeia Norte Editora, Brasil, 54-65.

[6] Pupiro, M.L. and Malagón Rodríguez, L. (2003) Técnicas del diagnóstico de las enfermedades en las plantas. Trabajo de patología vegetal. Universidad Agraria de La Habana, La Habana.

[7] Macias Figueroa, O.L., Delgado Calvo, Y., Peña Marrero, E., Betancourt, R.L. and Barreto, R.E. (2006) Técnicas para el diagnóstico y determinación de variabilidad genética de fitopatógenos. Universidad de Matanzas "Camilo Cienfuegos”, Matanzas.

[8] Pappas, M.G., Hajkowski, R. and Hockmeyer, W. (1983) Dot Enzyme-Linked Immunosorbent Assay (DOT-ELISA) a Microtechnique for the Rapid Diagnosis of Visceral Leishmaniasis. Journal of Immunological Methods, 64, $205-214$. http://dx.doi.org/10.1016/0022-1759(83)90399-X

[9] Ferrer Gual, R.M. (2008) Caracterización molecular y desarrollo de métodos de diagnóstico del género Fabavirus. Evaluación del BTH como método control. Tesis doctoral. Universidad Politécnica de Valencia, Valencia.

[10] Towbin, A., Staehelin, T. and Gordon, J. (1979) Electrophoretic Transfer of Proteins from Polyacrylamide Gels to Nitrocellulose Sheets: Procedure and Some Applications. Proceedings of the National Academy of Sciences of the United States of America, 76, 4350-4354. http://dx.doi.org/10.1073/pnas.76.9.4350

[11] Agudelo-Flórez, P. and Palacio, L.G. (2009) Dot blot para el diagnóstico de la cisticercosis porcina. Scientific and Technical Review of the Office International des Epizooties, 28, 1077-1084.

[12] Cabezas Vergara, C., Parcha, C., Pineda, J. and Reyes Arenas, E. (2006) Estandarización de una técnica de amplificación genómica (PCR) para el diagnóstico de Dermatofitos. Ciencia \& Trabajo, 8, 167-171.

[13] Rico Guerrero, L., Medina Ramos, S., Muñoz Sanchez, C.I., Guevara Olvera, L., Guevara González, R.G., Guerrero Aguilar, B.Z., Torres Pacheco, I., Rodriguez Guerra, R. and González Chavira, M.M. (2004) Detección de Phytophthora capsici Leonian en plantas de chile (Capsicum annuum L.) mediante PCR. Revista Mexicana de Fitopatología, 22, 1-6.

[14] Saavedra Rodríguez, C.O., Gómez González, S.J. and Ángel Díaz, J.E. (2004) Detección de secuencias específicas de ADN de Spongospora subterranea en suelo y tubérculos de papa. Revista Colombiana de Biotecnología, 6, 14-22.

[15] Lurá, M.C., Latorre Rapela, M.G., Vaccari, M.C., Maumary, R., Soldano, A., Mattio, M. and González, A.M. (2011) Genetic Diversity of Cercospora kikuchii Isolates from Soybean Cultured in Argentina as Revealed by Molecular Markers and Cercosporin Production. Mycopathologia, 171, 361-371. http://dx.doi.org/10.1007/s11046-010-9362-x

[16] Moreno, N. and Agudelo-Flórez, P. (2010) Aplicación de las pruebas de PCR convencional simple y múltiples para la identificación de aislamientos de Leptospira spp. en Colombia. Revista Peruana de Medicina Experimental y Salud Pública, 27, 548-556. http://dx.doi.org/10.1590/S1726-46342010000400009

[17] Latorre Rapela, M.G., Maumary, R., Marcipar, I. and Lurá, M.C. (2013) Modelo experimental de infección de plantas de soja por especies de Cercospora. Revista FABICIB, 17, 66-73

[18] Rollins, J.A., Ehrenshaft, M. and Upchurch, R.G. (1993) Effects of Light- and Altered-Cercosporin Phenotypes on Gene Expression in Cercospora kikuchii. Canadian Journal Microbiology, 39, 118-124. http://dx.doi.org/10.1139/m93-017

[19] Bradford, M.M. (1976) A Rapid and Sensitive Method for the Quantitation of Microgram Quantities of Protein Utilizing the Principle of Protein-Dye Binding. Analytical Biochemistry, 72, 248-254. http://dx.doi.org/10.1016/0003-2697(76)90527-3

[20] Lartey, R.T., Caesar-TonThat, T.C., Caesar, A.J., Shelver, W.L., Sol, N.I. and Bergman, J.W. (2005) Safflower: A New Host of Cercospora beticola. Plant Disease, 89, 797-801. http://dx.doi.org/10.1094/PD-89-0797

[21] Lee, S.B. and Taylor, J.W. (1992) Phylogeny of Five Fungus-Like Protoctistan Phytophthora Species, Inferred from the Internal Transcribed Spacers of Ribosomal DNA. Molecular Biology and Evolution, 9, 636-653.

[22] Sambrook, J., Fritsch, E.F. and Maniatis, T. (1989) Molecular Cloning: A Laboratory Manual. Cold Spring Harbor Laboratory Press, New York.

[23] Ward, E., Foster, S.J., Fraaije, B.A. and McCartney, H.A. (2004) Plant Pathogen Diagnostics: Immunological and Nucleic Acid-Based Approaches. Annals of Applied Biology, 145, 1-16. http://dx.doi.org/10.1111/j.1744-7348.2004.tb00354.x

[24] Ndao, M. (2009) Diagnosis of Parasitic Diseases: Old and New Approaches. Interdisciplinary Perspectives on Infectious Diseases, 2009, Article ID: 278246. http://dx.doi.org/10.1155/2009/278246

[25] Arboleda, V.J.W., Delgado, B.F. and Valencia, J.A. (2004) Detección de beauvericina en el hongo entomopatógeno Beauveria bassiana mediante el uso de anticuerpos policlonales. Revista Colombiana de Entomología, 30, 125-130.

[26] Shaheen, H.I., Kamal, K.A., Farid, Z., Mansour, N., Boctor, F.N. and Woody, J.N. (1989) Dot-Enzyme-Linked Immunosorbent Assay (Dot-ELISA) for the Rapid Diagnosis of Human Fascioliasis. Journal of Parasitology, 75, 549-552. 
http://dx.doi.org/10.2307/3282904

[27] Swarna, S.R. and Parija, S.C. (2008) Dot-ELISA for Evaluation of Hydatid Cyst Wall, Protoscoleces and Hydatid Cyst Fluid Antigens in the Serodiagnosis of Cystic Echinococcosis. Revista do Instituto de Medicina Tropical de São Paulo, 50, 233-236. http://dx.doi.org/10.1590/S0036-46652008000400009

[28] Chen, Y., Xu, F., Fan, X., Luo, H., Ge, S., Zheng, Q., Xia, N, Chen, H., Guan, Y. and Zhang, J. (2008) Evaluation of a Rapid Test for Detection of H5N1 Avian Influenza Virus. Journal of Virological Methods, 154, 213-215. http://dx.doi.org/10.1016/j.jviromet.2008.08.013

[29] Roldán, W.H. and Espinoza, Y.A. (2009) Evaluation of an Enzyme-Linked Immunoelectrotransfer Blot Test for the Confirmatory Serodiagnosis of Human Toxocariasis. Memorias do Instituto Oswaldo Cruz, 104, 411-418. http://dx.doi.org/10.1590/S0074-02762009000300003

[30] Belo, E.F., Farhat, C.K. and Gaspari, E.N. (2010) Comparison of Dot-ELISA and Standard ELISA for Detection of Neisseria meningitidis Outer Membrane Complex-Specific Antibodies. Brazilian Journal of Infectious Diseases, 14, 35-40.

[31] Piña, R.R., Gutiérrez, A.H., Gilman, R.H., Rueda, D., Sifuentes, C., Flores, M., Sheen, P., Rodriguez, S., García, H.H. and Zimic, M. (2011) A Dot-ELISA Using a Partially Purified Cathepsin-L-Like Protein Fraction from Taenia solium Cysticerci, for the Diagnosis of Human Neurocysticercosis. Annals of Tropical Medicine and Parasitology, 105, 311318. http://dx.doi.org/10.1179/136485911X12987676649782

[32] Xu, M.L., Melchinger, A.E. and Lübberstedt, T. (1999) Species-Specific Detection of the Maize Pathogens Sporisorium reiliana and Ustilago maydis by Dot Blot Hybridization and PCR-Based Assays. Plant Disease, 83, 390-395. http://dx.doi.org/10.1094/PDIS.1999.83.4.390

[33] Pavón Moreno, M.A., García Lacarra, T. and Martín de Santos, R. (2008) Utilización del gen Alt a1 para la detección de Alternaria spp. en productos hortofrutícolas mediante una técnica de PCR. Revista Complutense de Ciencias Veterinarias ( $R C C V), 2,105-113$.

[34] Lartey, R., Weiland, J., Caesar, T. and Bucklin Comiskey, S. (2003) A PCR Protocol for Rapid Detection of Cercospora beticola in Infected Sugar Beet Tissues. Journal of Sugar Beet Research, 40, 1-10. http://dx.doi.org/10.5274/jsbr.40.1.1

[35] Daub, M.E., Herrero, S. and Chung, K.R. (2005) Photoactivated Perylenequinone Toxins in Fungal Pathogenesis of Plants. FEMS Microbiology Letters, 252, 197-206. http://dx.doi.org/10.1016/j.femsle.2005.08.033

[36] Chanda, A.K., Ward, N.A., Robertson, C.L., Chen, Z.-Y. and Schneider, R.W. (2014) Development of a Quantitative Polymerase Chain Reaction Detection Protocol for Cercospora kikuchii in Soybean Leaves and Its Use for Documenting Latent Infection as Affected by Fungicide Applications. Phytopathology, 104, 1118-1124. http://dx.doi.org/10.1094/PHYTO-07-13-0200-R

[37] Agarwal, V.K. and Sinclair, J.B. (1997) Principles of Seed Pathology. 2nd Edition, CRC Press/Lewis Publishers, Boca Ratón. 